\title{
A Johansen Cointegration Test for the Relationship between Remittances and Economic Growth of Japan
}

\author{
Suwastika Naidu ${ }^{1}$, Atishwar Pandaram ${ }^{1} \&$ Anand Chand \\ ${ }^{1}$ School of Management and Public Administration, The University of the South Pacific, Fiji \\ Correspondence: Suwastika Naidu ${ }^{1}$, School of Management and Public Administration, Faculty of Business and \\ Economics, The University of the South Pacific, Private Mail Bag, Suva, Fiji Islands. Tel: 679-3231-981. E-mail: \\ naidu_s@usp.ac.fj
}

Received: September 10, 2017 Accepted: September 20, 2017 Online Published: September 30, 2017

doi:10.5539/mas.v11n10p137 URL: https://doi.org/10.5539/mas.v11n10p137

\begin{abstract}
Remittance inflows have been a key stimulus to economic growth of many developing countries. There is scant literature available on the impact of remittance inflows and outflows on the economic growth of the large developed countries. For instance, there is little literature on the impact of remittance inflows and outflows on the economic growth rate of Japan. Hence this research objective of this paper is to investigate the relationship between 'remittance inflows' and 'outflows' on the 'economic growth rate' of Japan. The paper by utilizing the World Bank data set and the econometric model namely the Granger Causality Model to test and analysis the impact of remittance inflows and outflows on the economic growth rate of Japan. The findings show that in the long run, a $1 \%$ increase in remittance outflows will decrease GDP growth rate by $0.000793 \%$. In the short run, a $1 \%$ increase in remittance outflows and inflows will decrease GDP growth rate by $0.000599 \%$ and $0.000327 \%$ respectively. The Japanese government should encourage retired Japanese workers to return to the labour market and effectively contribute to the workforce and retired workers can be re-trained so that less foreign migrant workers are needed and this will reduce remittance outflow.
\end{abstract}

Keywords: remittance, GDP growth rate, Johansen Cointegration Test, short run, long run, developed countries, granger causality test

\section{Introduction}

There are a number of benefits of remittance inflows to both developed and developing countries. First, remittance has become a vital source of income to developing countries (Rao and Hassan 2012). The GDP per capita of developing countries is lower than that of the developed countries. For instance, as of year 2015, the GDP per capita of China was US\$8027.70 while the GDP per capita of Japan was US\$32,477.2 (World Bank 2017). This implies that residents of China have much less per capita income to spend on consumption as compared to the residents of Japan. As a result of this, the residents of China may migrate to Japan in order to send their earned income from Japan to their families in China. These types of transfers are classified as remittances (World Bank 2017). It has been polarised in the existing literature that remittances received by low GDP per capita countries are usually significantly higher than high GDP per capita countries (Taylor 1999). Second, skilled migration generates remittances and it is economically viable for the developing countries to train skilled workers for export (Goldfarb et al. 1984). Additionally, the developed countries benefit as skilled workers are able to transfer their skills and core competencies from the developing countries to the developed countries. Third, cash sent by employees working in the developed countries to their relatives in the developing countries has turned out to be the second largest form of inflows and is next to foreign direct investment (Aggrawal et al. 2011).

Furthermore, there are many studies that have argued that remittance has a positive impact on the economic growth of the developing countries (Nica 2014; Bettin et al. 2015; Kratou 2016). Nevertheless, there are only a few studies that have explored the impact of remittance inflows and outflows on the economic growth of the developed countries (Jawaid and Raza 2012). To the best of our knowledge, none of the existing studies have empirically explored the impact of remittance inflows and outflows on the economic growth rate of Japan. Japan has always experienced the effects of net negative remittances. This connotes that more transfers of cash and kind moves out of Japan than those coming in (World Bank 2016). 
The low economic growth rates experienced by Japan have captured global attention, as a stagnating Japanese economy may trigger global recession if this macroeconomic problem is not effectively diagnosed and addressed (Harada 2016). A close synthesis of the Japanese economic growth rate shows that per annum volatility of Japanese growth rate is very high which is a rare and an unusual phenomenon to be noticed in the growth rates of other developed nations, such as, the US, UK, Australia, Russia and Germany. One of the key factors that may be responsible for this declining growth rate is the number of foreign immigrant workers working in Japan and sending millions of dollars of remittances to their families abroad. Hence, the impact of remittance inflows and outflows on the economic growth rate of Japan needs to be empirically scrutinized (Tezuka 2016).

Moreover, this study fills the research lacuna in the existing literature in four ways. First, it uses robust econometric models to examine the relationship between remittance inflows and outflows on the economic growth rate of Japan. The short run analysis has captured the innovation disturbance effect that is thoroughly explained in the discussion section. Second, this study integrates the impact of remittance inflows and outflows on the household's consumption patterns by using the Keynesian demand function. Third, this study also explains the impact of remittance inflow and outflow on the individual household's budget constraint. It has been argued that remittance inflows will shift the budget constraint line of the household upward and remittance outflows will shift the budget constraint line of the household downward. Fourth, this paper also integrates the impact of remittance inflows and outflows on the macroeconomic balance equation.

This paper is structured as follows. Section two provides the overview of remittance and the economic growth rate of Japan. Section three discusses the theoretical models related to remittances and economic growth rate. Section four provides literature review. Section five outlines the sources of data used in this study. Section six outlines the model specification. Section seven presents the research findings and section eight discusses the research findings. Section eight outlines the policy implications and section nine presents the conclusion and limitations of this study.

\section{Overview of Remittance and Economic Growth Rate of Japan}

The foreign workers in Japan are mainly from China, North Korea and South Korea. With the current demographic problem of declining birth rates and a dramatic increase in the elderly population, a rapid increase in the foreign workers working in Japan is bound to incur. The Japanese government's immigrant foreign worker policy seeks to encourage qualified, skilled and talented workers to become part of the Japanese workforce (Tezuka 2016). According to Hamada and Otsuka (2011), as compared to the United States, Japan has been less open to immigrant workers. Nevertheless, if one compares the remittances sent by the immigrant workers from Japan, it is far more than the remittances sent by the immigrant workers from the United States. In Japan, the immigrant workers are more educated than the immigrant workers in the United States. The statistics reveal that the net remittances have been negative since the last three decades as immigrant workers from Japan send more money to their relatives living aboard as compared to the money received by families of Japanese workers working abroad in foreign countries (Hamada and Otsuka 2011). The financial intermediary cost of sending money is 3\% in Japan while in the United States it is 7\% (Hamada and Otsuka 2011). The cost of sending money is $133.33 \%$ higher in the United States as compared to Japan. Figure one shows the remittance inflows, remittance outflows and net remittances of Japan.

Figure 1 shows that the remittance outflows have increased from US\$1298.41(million) in the year 1991 to US\$3999.74 (million) in the year 2015. Remittance inflows have also increased from US\$508.11(million) in the year 1991 to US\$3670.25 (million) in the year 2015 (World Bank 2016; Knoema 2016). The net remittances have always been a negative figure for the Japanese economy. This implies that workers are making more personal transfers of cash and kind out of Japan as compared to what is received by the Japanese residents and non-residents. 


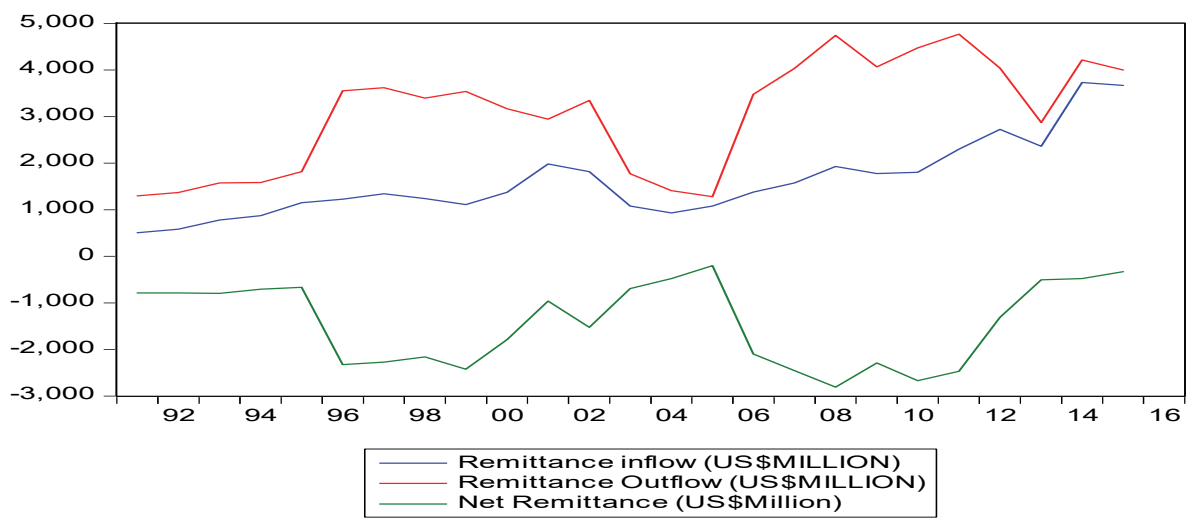

Figure 1. Remittance Inflows and Outflows and Net Remittance of Japan

Source: Developed by the authors of this paper by using data from the World Bank (2016) and https://knoema.com/ database.

After the World War II, the Japanese economy used to be regarded as the global economic powerhouse as it used to record economic growth rates of around $10 \%$ (World Bank 2016). Until recently, the growth of the Japanese economy has stagnated and economists are diagnosing where the policy prescriptions went wrong. The stagnating growth of the Japanese economy will affect the macroeconomic performance of Asia that can trigger a global recession. According to Harada (2016), as compared to the 1990's, the unemployment rates have risen from the year 1990. The high unemployment rates in Japan imply that tax revenues received by the Japanese government are low, and social security and economic welfare of citizens is declining. Figure 2 shows the GDP growth rates of Japan.

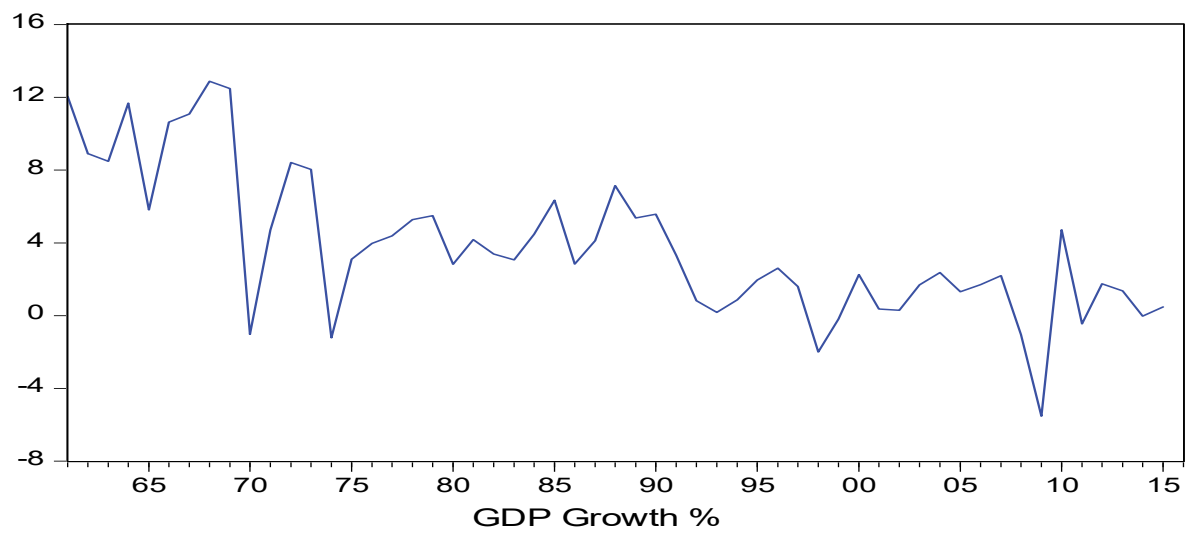

Figure 2. GDP Growth Rates of Japan

Source: Developed by the authors of this paper by using data from the World Bank (2016) database.

Figure two shows the GDP annual growth rates of Japan. Similar, to the situation in many Asian countries, the economic growth rate of Japan has been extremely volatile in the recent years. This figure shows that the economic growth rate of Japan decreased from $12.04 \%$ in the year 1961 to $0.47 \%$ in the year 2015 . A close analysis of 10 year interval annual growth rate shows that the highest growth rate of Japan has been recorded between the periods 1960 to 1970 . The GDP growth rate after this period has generally declined (International Monetary Fund 2016).

The next sub-section will outline the theoretical models related to remittance and the economic growth rate.

\section{Theoretical Models Related to Remittance and Economic Growth Rate}

The main aim of this section is to outline the role of remittances in an individual household's daily consumption needs and the relationship between remittances and economic growth rate. Existing studies on remittances have mainly focused on developing countries, particularly the small island developing countries, where remittances play a significant role in their economic growth rates (Brown and Ahlburg 1999; Connell and Conway 2000; Nica 
2014; Bettin et al. 2015). The small island developing countries are constrained by underdeveloped tradable sector. As a result of this, many talented and skilled workers have to migrate to developed countries in search for greener opportunities. Once a migrant worker secures a worthy employment in the developed countries, they usually send remittances that include cash in the form of gifts to their families abroad (Bettin et al. 2015; Cortes 2015).

There are two core issues that are of interest to both the developed and developing countries and these are as follows: (1) remittance inflows will increase domestic consumption and household disposable income (Azam 2015; Dey 2015) and (2) remittance outflow will decrease domestic consumption and household disposable income (David and Marouani 2015). This phenomenon can be effectively captured by the Keynesian demand function which is given as follows:

$$
Y_{t}=C_{t}+I_{t}(1)
$$

In equation $1, Y_{t}$ is disposable income, $C_{t}$ is consumption expenditure, $I_{t}$ is investment and $t$ represents any given time period. When households receive remittances, the consumption by the recipient household increases by the amount of remittances received. Conversely, when a household sends remittance, the consumption by this household decreases by the amount of remittances outflows. This can be effectively captured in equations two and three as follows:

$$
Y_{t}+R E M I_{t}=\left(C_{t}+R E M I_{t}\right)+I_{t}
$$

In equation two, REMI represents remittance inflows and it increases the total consumption of the household. Additionally, $\mathrm{REMI}_{\mathrm{t}}$ increases the total household income by the amount of remittance inflows.

$$
Y_{t}-R E M O_{t}=C_{t}-R E M O_{t}+I_{t} \text { (3) }
$$

In equation three, $\mathrm{REMO}_{\mathrm{t}}$ represents remittance outflows and it decreases the total consumption of the donor household. It also decreases the total donor household income by the amount of remittance outflows.

Remittances and Households Budget Constraint: There are many empirical and non-empirical studies often argue that remittance inflows will improve the livelihood of the recipient countries while simultaneously deteriorating the welfare of the donor countries. Cox-Edwards and Ureta (2003) found that children from remittance recipient households are less likely to drop out of school as compared to their counterparts. Acosta et al. (2007) found that remittances reduce the incidence of poverty in the Latin American countries. Calero et al. (2009) argued that remittance inflows have a positive impact on human capital investments as it relaxes household's resource constraints. Bettin et al. (2015) study based on 103 Italian provinces found that remittance outflows are negatively correlated to the economic cycle. Adarkwa (2015) proved that remittances increases the recipient household's income and reduces poverty in Cameroon, Cape Verde, Nigeria and Senegal. Assume that an employee has to allocate Y dollars for purchasing a combination of good A and good B. This employee's budget constraint is given as follows (see figure 3):

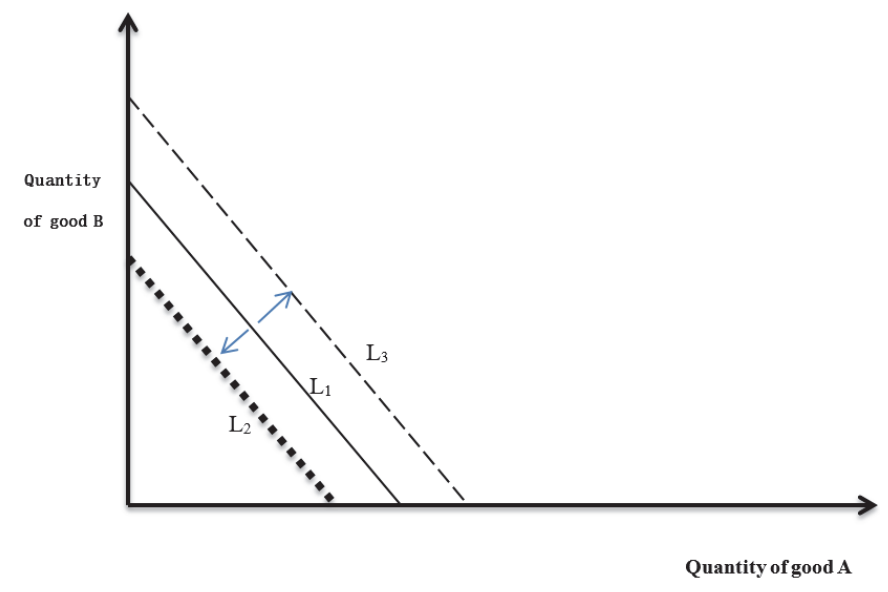

Figure 3. Budget Constraint of an Employee

Source: Created by the Authors of this paper by using empirical evidences from Acosta et al. (2007), Bettin et al. (2015) and Adarkwa (2015).

As illustrated in figure 3, an employee's budget constraint, depicted by line $\mathrm{L}_{1}$, can be captured by the following equation: 


$$
P_{A} A+P_{B} B \leq Y_{t}
$$

In equation $4, P_{A}$ is price of good $\mathrm{A}, \mathrm{A}$ is quantity of good $\mathrm{A}, P_{B}$ is price of good $\mathrm{B}$ and $\mathrm{B}$ is quantity of good $\mathrm{B}$. As argued by Cox-Edwards and Ureta (2003), Acosta et al. (2007) and Calero et al. (2009), remittance inflows will lead to a parallel shift of $\mathrm{L}_{1}$ by relaxing household's financial constraints. Therefore, the new budget constraint for the family receiving the remittance will be $\mathrm{L}_{3}$. This is captured by the following equation:

$$
P_{A} A+P_{B} B \leq Y_{t}+R E M I_{t}(5)
$$

In equation $5, \mathrm{REMI}_{\mathrm{t}}$ is remittance inflows at time period t. Similarly, remittance outflows will have an opposite effect on the budget constraint of the employee sending the remittance. The employee sending the remittance will have less income at his disposal, so the new budget constraint for the employee is captured by line $\mathrm{L}_{2}$. The equation for line $\mathrm{L}_{2}$ is given below:

$$
P_{A} A+P_{B} B \leq Y_{t^{-}} R E M O_{t}
$$

In equation $6, \mathrm{REMO}_{\mathrm{t}}$ is remittance outflows at time period t. Remittance inflows and outflows is not only a microeconomic phenomenon but it is also a macroeconomic phenomenon that has an impact on the economic growth rate. The effect of remittance inflows and outflows on the macroeconomic balance equation is transmitted by the effect that remittances have on the household consumption expenditure. Therefore, substituting equation 3 and 4 in the macroeconomic balance equation, we get:

$$
Y_{t}+R E M I_{t}-R E M O_{t}=\left(C_{t}+R E M I_{t}-R E M O_{t}\right)+I_{t}+G_{t}+\left(X_{t}-M_{t}\right)
$$

In equation $7, Y_{t}$ is national income, $C_{t}$ is consumption expenditure, $I_{t}$ is investment expenditure, $G_{t}$ is government expenditure and $X_{t}-M_{t}$ represents net exports. Equation 7 shows that remittance inflows will increase national income and vice versa.

\section{Literature Review}

One of the main arguments underpinning the studies on remittances states that workers from developing countries feeds into the production process of the developed countries and provide a source of competitive advantage to the developed countries (Peri 2016). In return, these workers earn income and a portion of this income is sent by these workers to their families living abroad. Workers with versatile skills contribute immensely to knowledge everywhere and these exceptional individual's contributions encompass scientific discoveries and innovation (Kerr et al. 2016). The economic impact of remittance flows upon income distribution and growth has generated immense attention; nonetheless, the empirical and theoretical literature on the association between economic growth and remittance in the context of the developed countries is still unclear (Gianneti et al. 2009). The existing studies on remittances can be divided into two categories; namely, developing and developed countries.

\section{Studies on Inflows and Outflows of Remittances and Economic Growth in Developing Countries}

To begin with, there are numerous studies conducted on remittances and economic growth of the developing countries. Kratou (2016) investigated the impact of remittances of workers on the economic growth of the MENA (Middle East and North African region) countries by using the co-integration econometric analysis. This study concluded that remittance outflows to the recipient countries' have a conclusive and direct impact on their economic growth rate in the long run and an adverse impact in the short run. Nonetheless, it was also found that in the short run, the impact of remittance inflows on economic growth rate was moderated by the extent of financial development and institutional quality. Gyimah-Brepong and Asiedu (2015) found that remittance inflows to recipient countries have enhanced their possibilities for economic growth and have been responsible in reducing poverty in the long run for these African countries. Jackman et al. (2009) confirmed that the remittance inflows exert a stabilizing effect on investment volatility and output in the small island developing countries.

Moreover, Azam (2015) confirmed the presence of a positive, that is, significant and a direct relationship between economic growth and inflows of remittances from migrant workers in the four South Asian countries, namely, Pakistan, India, Bangladesh and Sri Lanka. Also Mundaca (2009) demonstrated that inflows of remittances have a significant and a direct long run positive impact on the economic growth of the Caribbean and Latin American countries. Jawaid and Raza (2012) investigated the association between economic growth and inflows of remittances in Korea and China over a 30 year period. This study found that there exist a significant long run positive association between economic growth and remittances in Korea; however, for China a significant negative association existed between economic growth and remittances. Rao and Hassan (2012) explored direct and indirect growth effects of remittances of 40 leading recipient nations. They ascertained that 
inflows of remittance had small indirect effects on the economic growth rates of countries. Adams et al. (2016) found that inflows of remittance do not have any effect on the growth of the economies in Sub-Saharan Africa. Guha's (2013) investigation shows that remittances received by developing countries have changed household budgets and have directly impacted on their decision making, consumption behavior and commitment at micro-levels.

\section{Studies on Inflows and Outflows of Remittances and Economic Growth of Developed Countries}

Furthermore, Goto (1998) used the Computable General Equilibrium (CGE) model and investigated the effect of unskilled and illegal migrant workers in Japan's economy. This study unveiled that if Japan was to benefit from immigrant workers, then they should only allow highly qualified and skilled workers to enter the Japanese workforce. The number of workers allowed to enter the Japanese workforce should be aligned to the production needs of the nation. An excess labor supply will lead to unemployment and deflation and this may have long term devastating impact on the economy. World Bank (2015) highlighted that due to slow growth of the Russian and the European economies, the remittance outflows to the developing countries will dramatically decline. Pradhan (2016) used the Fully Modified Ordinary Least Square (FMOLS) estimator and found that remittance inflows have a negative effect on the economic growth rate of the Russian Federation.

A close synthesis of the studies on remittance inflows, outflows and economic growth rate shows that there are numerous studies conducted on the impact of remittance inflows on economic growth rate of the developing countries, while there are only a handful of studies conducted on the impact of remittance inflows on the economic growth rate of the developed economies. There is only one study conducted by Pradhan (2016) that used the Fully Modified Least Square Estimator to examine the impact of remittance inflows on the economic growth rate of the Russian Federation. However, there are two disadvantages of using the FMOLS that questions the validity of the research findings generated by using this estimator (Kao and Chiang, 1999). First, the FMOLS is biased in heterogeneous panels. Second, the FMOLS is biased when the serial correlation parameter is more than or equal to zero and the endogeneity parameter is more than zero.

\section{Data Collection}

The main aim of this paper is to examine the relationship between remittance inflows, remittance outflows and economic growth rate of Japan. To achieve this aim, data on remittance inflows and outflows were collected from the World Bank and Knoema database. Data on economic growth rate was collected solely from the World Bank database. Data on remittance inflows and outflows were given in US dollars (millions) while the GDP growth rate was given as a percentage. Data on GDP growth rate was collected from year 1961 to 2015 and data on remittance inflows and outflows was collected from 1977 to 2015. This resulted in 39 observations for remittance inflows and outflows and 55 observations for GDP growth rate. Following the studies conducted by Christensen et al. (1973), Kumbhakar and Lovell (2000) and Growitsch et al. (2009), this study converted all the variables in the log form before conducting the analysis for two reasons. First, if the variables are used as logs, then the coefficients of the co-integrating vector can be treated as long run elasticities. Second, it makes the interpretation of the long run and short run coefficients much easier when both the independent and dependent variables are given in the log form (Adhikary, 2011).

\section{Model Specification}

This section will outline the econometric model specification for the GLS transformed Dickey-Fuller (DFGLS), Phillips-Perron (PP), Bai and Perron's sequentially determined multiple breakpoint test, Johansen's Cointegration test and Granger Causality test. The functional form of the variables investigated in this study is proposed as follows:

$$
G D P G R_{t}=f\left(R E M O_{t}, R E M I_{t}\right)
$$

In equation $8, \mathrm{GDPGR}_{\mathrm{t}}$ is the gross domestic product growth rate, $\mathrm{REMO}_{\mathrm{t}}$ is the remittance outflows and $\mathrm{REMI}_{\mathrm{t}}$ is the remittance inflows.

\subsection{GLS transformed Dickey-Fuller (DFGLS) And Phillips-Perron (PP)}

The GLS transformed Dicky Fuller test extends the Augmented Dicky Fuller test by de-trending the LGDPGR $\mathrm{LREMO}_{\mathrm{t}}$ and LREMI . There are two important reasons for de-trending the time series data before conducting any analysis. First, presence of trends in the data implies that the relationships of interest in the analysis will be distorted by the presence of these trends. Removal of these trends in the time series data before conducting the analysis ensures that the analysis is free from this distortion (University of Massachusetts Dartmouth 2016). Second, as the de-trending mechanism is in-built in the DFGLS test, there is no need to run the de-trending analysis on the time series data in order to prepare the dataset for further analysis. The test equation for the GLS 
transformed Dicky Fuller test is expressed below (Elliott et al. 1996):

$$
\begin{gathered}
\Delta L G D P G R_{t}^{d}=\alpha L G D P G R_{t-1}^{d}+\beta_{1} \Delta L G D P G R_{t-1}^{d} \cdots+\beta_{n} \Delta L G D P G R_{t-n}^{d}+v_{t} \\
\triangle L R E M I_{t}^{d}=\alpha L R E M I_{t-1}^{d}+\beta_{1} \Delta L R E M I_{t-1}^{d} \cdots+\beta_{n} \Delta L R E M I_{t-n}^{d}+v_{t} \\
\Delta L R E M O_{t}^{d}=\alpha L R E M O_{t-1}^{d}+\beta_{1} \Delta L R E M O_{t-1}^{d} \cdots+\beta_{n} \Delta L R E M O_{t-n}^{d}+v_{t}
\end{gathered}
$$

In equations 9,10 and 11 , ' $\mathrm{d}$ ' is de-trended equation, $\mathrm{v}_{\mathrm{t}}$ is the disturbance term and $\mathrm{t}$ is time period. Furthermore, one of the main reasons for choosing the Phillips and Perron's (1988) test, aka PP test, is that it allows for controlling of serial correlation when testing for the presence of a unit root. The equation for the PP test is given as follows (Phillips 1987; Phillips and Perron 1988; Phillips and Xiao, 1998):

$$
t_{\alpha}=t_{\alpha}\left(\frac{\delta_{0}}{\vartheta_{0}}\right)^{0.5}-\frac{T\left(\operatorname{se}(\widehat{\alpha})\left(\vartheta_{0}-\delta\right)\right.}{2 \vartheta_{0}^{2} s}
$$

In equation $12, \alpha$ is the standard coefficient, $s e(\widehat{\alpha})$ is the standard error of the coefficient, $\mathrm{s}$ is the standard error of the test regression, $\delta_{0}$ is the estimate of the error variance and $\vartheta_{0}$ is the estimator of the residual spectrum.

\subsection{Bai and Perron's Sequentially Determined Multiple Breakpoints Test}

This study uses the Bai and Perron's sequentially determined multiple breakpoints test for a number of reasons. First, it provides a consistent estimate of the breakpoint dates that accounts for structural changes in the series. Second, it also provides the confidence intervals for the break dates. The equation that captures the Bai and Perron's sequentially determined multiple breakpoints test is given below (Bai 1997; Bai and Perron 1998; Perron 2006):

$$
L G D P G R_{t}=\rho_{t} \omega+\vartheta_{t} \zeta+\pi_{t} \beta_{k}+\gamma_{t}
$$

In equation 13, $L G D P G R_{t}$ is the explained variable representing log of GDP growth rate, $\rho_{t}(\mathrm{a} \times 1), \vartheta_{t}(\mathrm{~b} \times 1)$, and $\pi_{t}(\mathrm{c} \times 1)$ are the vectors of $\log$ of remittance inflows (LREMI $)$ and remittance outflows $\left(\right.$ LREMO $\left._{t}\right)$ and $m$ accounts for breaks.

\subsection{Johansen's Co-integration Test}

The Johansen's co-integrating test is used in a multivariate framework. Before the Johansen's co-integration procedure can be applied to determine the number of co-integrating relationships between the dependent and independent variables, we have to determine whether the variables are $\mathrm{I}(0)$ or $\mathrm{I}(1)$ variables. If all the variables used in this study are I(1) variables, Johansen's co-integration test can be used to determine the number of co-integrating relationships between the dependent and independent variables. The basic equation that captures the Johansen's co-integration test is given below (Johansen, 1991, 1995):

$$
Z_{t}=A Z_{t-1}+\ldots+A_{n} Z_{t-n}+B x_{t}+\epsilon_{t}
$$

In equation $14, Z_{t}$ is the vector for the $\mathrm{I}(1)$ independent and dependent variables, $x_{t}$ is the vector of the non-random variable and $\epsilon_{t}$ is the error correction term.

\subsection{Granger Causality Test}

One of the common analyses that are applied in the existing literature to test the causal relationships between two variables is the Granger Causality test (Adenutsi 2011; Tekin 2012; Tang and Abosedra 2014). The Granger Causality test involves estimating two equations for the simple vector autoregression (VAR) for LGDPGR LREMO $_{t}$ and LREMI. The simple vector autoregression (VAR) for LGDPGR ${ }_{t}$ and LREMO ${ }_{t}$ is given in equation 15 and 16:

$$
\begin{aligned}
\text { LREMO }_{t} & =\sum_{i=1}^{n} \alpha_{i} \text { LGDPGR }_{t-i}+\sum_{i=1}^{n} \beta_{i} \text { LREMO }_{t-i}+\epsilon_{1 t} \\
\text { LGDPGR }_{t} & =\sum_{i=1}^{n} \alpha_{i} \text { LREMO }_{t-i}+\sum_{i=1}^{n} \beta_{i} \operatorname{LGDPGR}_{t-i}+\epsilon_{1 t}
\end{aligned}
$$

In equation 15 and $16, \mathrm{LGDPGR}_{\mathrm{t}}$ and $\mathrm{LREMO}_{\mathrm{t}}$ represent's the log of gross domestic product growth rate and log of remittance outflows respectively. The simple vector autoregression (VAR) for LGDPGR $\mathrm{t}_{t}$ and $\mathrm{LREMI}_{t}$ is captured in equations 17 and 18 :

$$
\begin{aligned}
\text { LREMI }_{t} & =\sum_{i=1}^{n} \alpha_{i} \operatorname{LGDPGR}_{t-i}+\sum_{i=1}^{n} \beta_{i} \text { LREMI }_{t-i}+\epsilon_{1 t} \\
\text { LGDPGR }_{t} & =\sum_{i=1}^{n} \alpha_{i} \text { LREMI }_{t-i}+\sum_{i=1}^{n} \beta_{i} \operatorname{LGDPGR}_{t-i}+\epsilon_{1 t}
\end{aligned}
$$

In equation 17 and 18, LGDPGR ${ }_{\mathrm{t}}$ and $\mathrm{LREMI}_{\mathrm{t}}$ represent's the log of gross domestic product growth rate and $\log$ 
of remittance inflows respectively. The simple vector autoregression (VAR) for $L R E M O_{t}$ and $L R E M I_{t}$ is captured in equations 19 and 20 :

$$
\begin{gathered}
\operatorname{LREMI}_{t}=\sum_{i=1}^{n} \alpha_{i} \text { LREMO }_{t-i}+\sum_{i=1}^{n} \beta_{i} \text { LREMI }_{t-i}+\epsilon_{1 t} \\
\text { LREMO }_{t}=\sum_{i=1}^{n} \alpha_{i} \text { LREMI }_{t-i}+\sum_{i=1}^{n} \beta_{i} \text { LREMO }_{t-i}+\epsilon_{1 t}
\end{gathered}
$$

In equation 19 and 20, LREMO ${ }_{t}$ and $L R E M I_{t}$ represent's the log of remittance inflows and remittance outflows respectively.

\section{Research Findings}

The results of the unit root tests are presented in table 1. According to the DF-GLS test, the LGDPGR $\mathrm{LREMO}_{\mathrm{t}}$ and LREMI $I_{t}$ are I (1) variables. A slightly different result is produced by the PP test. According to the PP test, LGDPGR $_{t}$ is I (0) variable whereas LREMO ${ }_{t}$ and LREMI $I_{t}$ are I (1) variables. Since both the test results show slightly different test results, we will use the DF-GLS unit root results as it de-trends the time series data while producing the unit root test results. The three time series data that we are using in this study has cyclical properties and by using DF-GLS test, we are able to remedy the distortions caused by this cyclical property of the data.

\begin{tabular}{|c|c|c|c|c|}
\hline Test & Integration Order & $L G D P G R_{t}$ & $\mathrm{LREMO}_{t}$ & $\operatorname{LREMI}_{t}$ \\
\hline \multirow[t]{3}{*}{ DF-GLS } & $\mathbf{I}(\mathbf{0})$ & -0.448401 & -0.824995 & 0.381331 \\
\hline & $\mathbf{I}(1)$ & $-8.778309 * * *$ & $-5.282902 * * *$ & $-5.780547 * * *$ \\
\hline & Decision & $\mathrm{I}(1)$ & $\mathrm{I}(1)$ & $\mathrm{I}(1)$ \\
\hline \multirow[t]{3}{*}{ PP } & $\mathbf{I}(\mathbf{0})$ & $-3.862458 * * *$ & -1.110603 & 1.128347 \\
\hline & $\mathbf{I}(\mathbf{1})$ & $-25.38447 * * *$ & $-6.245705^{* * *}$ & $-5.912333 * * *$ \\
\hline & Decision & $\mathrm{I}(0)$ & $\mathrm{I}(1)$ & $\mathrm{I}(1)$ \\
\hline
\end{tabular}

Table 1. DF-GLS and PP Unit Root Test Results for LGDPGR ${ }_{t}$, LREMO $_{t}$ and LREMI

Table 2 presents the Bai-Perron's test results for sequentially determined multiple breakpoints. According to this test, there are no breakpoints or structural breaks present in our time series data.

Table 2. Bai-Perron tests of $L+1$ vs. $L$ sequentially determined breaks

\begin{tabular}{cccc}
\hline \multicolumn{3}{l}{ Sequential F-statistic determined breaks: } & 0 \\
\hline & & Scaled & Critical \\
Break Test & F-statistic & F-statistic & Value** \\
0 vs. 1 & 2.858077 & 8.574231 & 13.98 \\
\hline
\end{tabular}

* Significant at the 0.05 level.

** Bai-Perron (Econometric Journal, 2003) critical values.

The lag length has to be determined before conducting the Johansen Cointegration test and Granger Causality test. Table 3 presents the results of the VAR Lag Order selection criteria for $\mathrm{LGDPGR}_{\mathrm{t}}, \mathrm{LREMO}_{\mathrm{t}}$ and $\mathrm{LREMI}_{\mathrm{t}}$. According to table 3, lag length of one is selected as the best lag length under the Final Prediction Error (FPE), Akaike Information Criterion (AIC), Schwarz Information Criterion (SIC), and Hannan-Quinn Information Criterion (HQ) criteria.

Table 3. VAR Lag Order Selection Criteria

\begin{tabular}{cccllll}
\hline Lag & LogL & LR & FPE & AIC & SC & HQ \\
\hline 0 & -536.9049 & NA & $2.98 \mathrm{e}+12$ & 37.23482 & 37.37627 & 37.27912 \\
1 & -493.0205 & $75.66279^{*}$ & $2.70 \mathrm{e}+11^{*}$ & $34.82900^{*}$ & $35.39478^{*}$ & $35.00619^{*}$ \\
2 & -489.7072 & 5.027110 & $4.09 \mathrm{e}+11$ & 35.22118 & 36.21130 & 35.53128 \\
* indicates lag order selected by the criterion & & & & \\
\hline
\end{tabular}


LR: sequential modified LR test statistic (each test at 5\% level)

FPE: Final prediction error

AIC: Akaike information criterion

SC: Schwarz information criterion

HQ: Hannan-Quinn information criterion

Table 4 shows the results of the Johansen's cointegration test. The results show that there is one cointegrating equation at $5 \%$ level of significance. Since there is one cointegrating equation as depicted in table 4 , we have to determine this co-integrating relationship by computing the long run coefficients.

Table 4. Johansen Cointegration Test for Unrestricted Cointegration Rank Test (Maximum Eigenvalue)

\begin{tabular}{ccccc}
\hline Hypothesized & \multicolumn{3}{c}{ Max-Eigen } & 0.05 \\
\hline No. of CE(s) & Eigenvalue & Statistic & Critical Value & Prob.** \\
None * & 0.536986 & 22.32997 & 21.13162 & 0.0338 \\
At most 1 & 0.141218 & 4.414962 & 14.26460 & 0.8131 \\
At most 2 & 0.009544 & 0.278118 & 3.841466 & 0.5979 \\
Max-eigenvalue test indicates 1 cointegrating eqn(s) at the 0.05 level \\
\hline * denotes rejection of the hypothesis at the 0.05 level \\
**MacKinnon-Haug-Michelis (1999) p-values \\
\hline
\end{tabular}

Equation 21 summarises the estimated long run beta coefficients, $t$-statistics and $p$ values for the long run relationship between LGDPGR ${ }_{t}$, LREMO $_{t}$ and LREMI $\mathrm{t}_{\mathrm{t}}$. A one unit increase in LREMO will decrease LGDPGR by 0.000793 units, ceteris paribus. This can be rewritten as a $1 \%$ increase in $\mathrm{REMO}_{\mathrm{t}}$ will decrease $\mathrm{GDPGR}_{\mathrm{t}}$ by $0.000793 \%$ (see calculation and outputs attached in the appendix).

$$
\begin{gathered}
L G \widehat{D P G} R_{t}=3.72-0.000125_{1} L_{R E M I_{t}}-0.000793_{2} \text { LREMO }_{t} \\
\mathrm{t}=(6.40)(-0.21)(-2.18) \\
\mathrm{p}=(0.00)(0.83)(0.03)
\end{gathered}
$$

Table 5 shows the diagnostic test results for the estimated beta coefficients, $t$-statistics and $p$ values for the long run relationship between LGDPGR $_{t}, \mathrm{LREMO}_{\mathrm{t}}$ and LREMI $\mathrm{t}_{\mathrm{t}}$. The Breusch-Pagan-Godfrey test does not reject the null hypothesis of homoscedasticity at $5 \%$ level of significance. Similarly, the Breusch-Godfrey Serial Correlation LM Test does not reject the null hypothesis of no serial correlation at $5 \%$ level of significance. The CUSUM's test shows that our model is stable and the Ramsey RESET test shows that our model is correctly specified.

Table 5. Diagnostic Test Results for the Long Run Relationship between LGDPGR $\mathrm{t}_{\mathrm{t}} \mathrm{LREMO}_{\mathrm{t}}$ and $\mathrm{LREMI}_{\mathrm{t}}$

\begin{tabular}{ll}
\hline Diagnostic Tests & Results \\
\hline Heteroscedasticity Test: Breusch-Pagan-Godfrey & F-Statistics: 2.818883 \\
& Prob. F(2,30): 0.0755 \\
Breusch-Godfrey Serial Correlation LM Test & F-Statistics: 1.060911 \\
& Prob. F(2,28): 0.3596 \\
Ramsey RESET Test & T-statistics: 1.600434 \\
& Prob.: 0.1203 \\
\hline
\end{tabular}




\section{CUSUM Test}

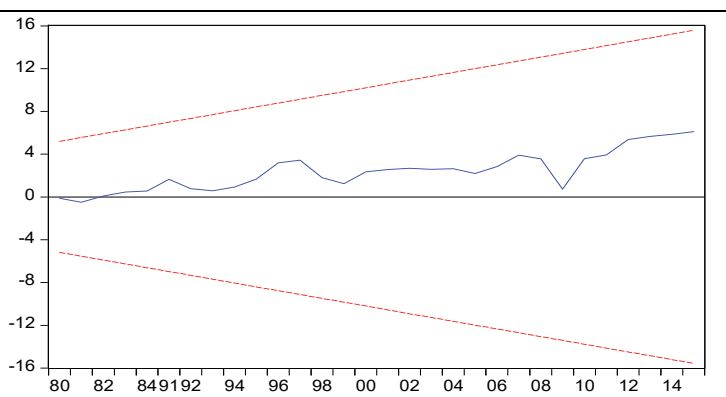

- CUSUM ---- $5 \%$ Significance

Equation 22 summarises the estimated short run beta coefficients, t-statistics and $\mathrm{p}$ values for the short run relationship between $\mathrm{LGDPGR}_{\mathrm{t}}, \mathrm{LREMO}_{\mathrm{t}}$ and $\mathrm{LREMI}_{\mathrm{t}}$. In the short run, a one unit increase in $\mathrm{LREMO}_{\mathrm{t}}$ will decrease LGDPGR $\mathrm{L}_{\mathrm{t}}$ by 0.000599 units at $1 \%$ level of significance, ceteris paribus. This can be rewritten as a $1 \%$ increase in $\mathrm{REMO}_{\mathrm{t}}$ will decrease $\mathrm{GDPGR}_{\mathrm{t}}$ by $0.000599 \%$ at $1 \%$ level of significance, ceteris paribus. Similarly, a one unit increase in $\mathrm{LREMI}_{\mathrm{t}}$ will decrease $\mathrm{LGDPGR}_{\mathrm{t}}$ by 0.000327 units at $1 \%$ level of significance, ceteris paribus This can be rewritten as a $1 \%$ increase in $\mathrm{REMI}_{\mathrm{t}}$ will decrease $\mathrm{GDPGR}_{\mathrm{t}}$ by $0.000327 \%$ at $1 \%$ level of significance, ceteris paribus. Equation 22 also shows that the error correction term is significant but not negative. Therefore, the disequilibrium in the model cannot be adjusted.

$$
L G \widehat{D P G} R_{t}=3.59_{0}-0.000327_{1} \Delta L R E M I_{t}-0.000599_{2} \Delta L R E M O_{t}+0.99_{4} E C T_{t}
$$

$\mathrm{t}=(17.54)(-1.63)(-4.94)(16.25)$

$\mathrm{p}=(0.1151)(0.00)(0.00)(0.00)$

Table 6 shows the diagnostic test results for the estimated short run beta coefficients, t-statistics and $\mathrm{p}$ values for the relationship between $\mathrm{LGDPGR}_{\mathrm{t}}, \mathrm{LREMO}_{\mathrm{t}}$ and LREMI . The Breusch-Pagan-Godfrey test, Breusch-Godfrey Serial Correlation LM Test, CUSUM's test and the Ramsey RESET test shows that our model is robust and free from all forms of statistical errors.

Table 6. Diagnostic Test Results for the Short run Relationship between LGDPGR, $\mathrm{LREMO}_{\mathrm{t}}$ and $\mathrm{LREMI}_{\mathrm{t}}$

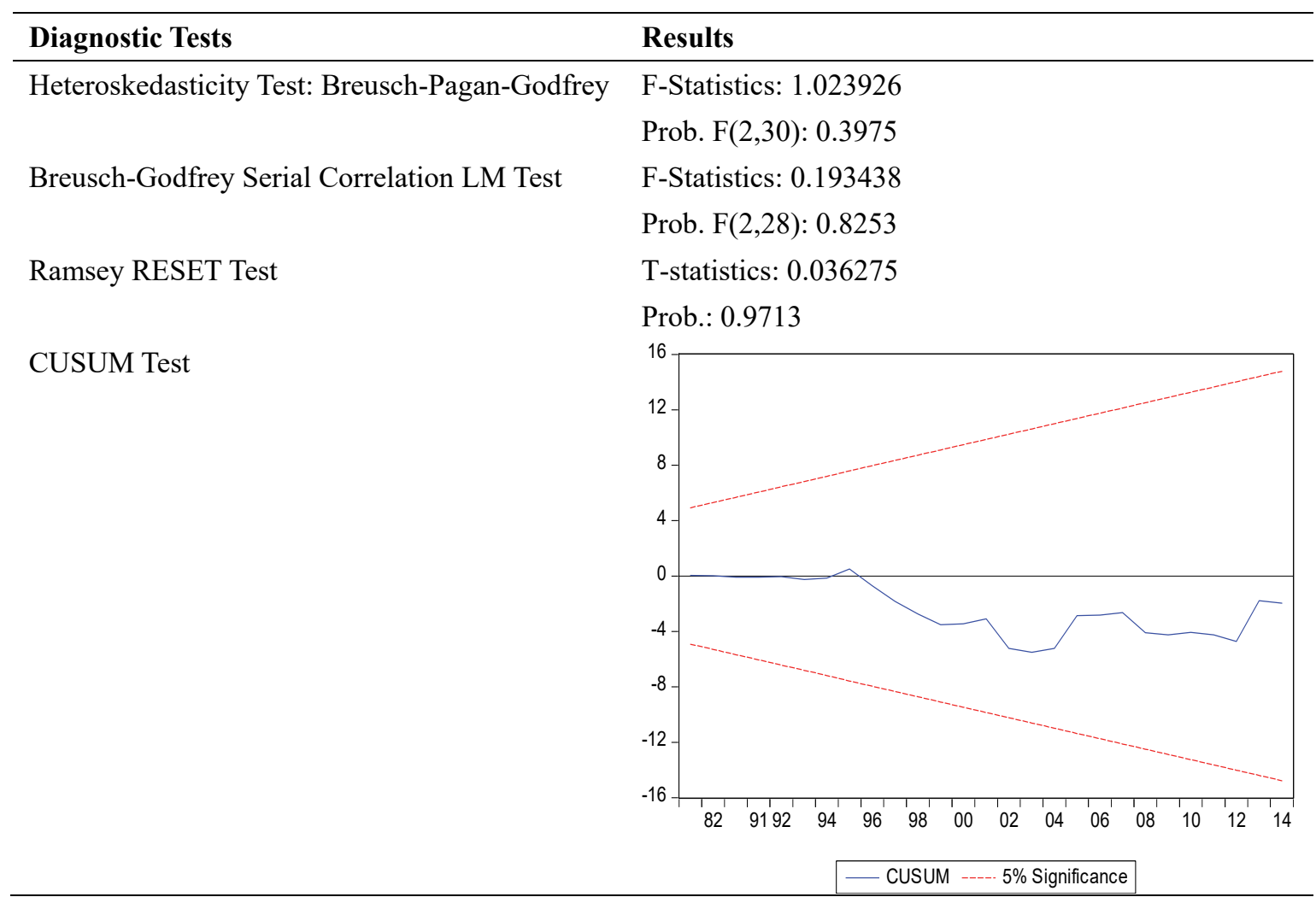


Table 7 shows the results of the pairwise Granger Causality test. The null hypothesis of 'REMIt does not Granger Cause GDPGR $_{\mathrm{t}}$ ' and ' $\mathrm{REMO}_{\mathrm{t}}$ does not Granger Cause GDPGR' ${ }_{\mathrm{t}}$ is rejected at $5 \%$ level of significance. Therefore, there is unidirectional causality running from $\mathrm{REMI}_{\mathrm{t}}$ and $\mathrm{REMO}_{\mathrm{t}}$ to $\mathrm{GDPGR}_{\mathrm{t}}$.

Table 7. Pairwise Granger Causality Test

\begin{tabular}{|c|c|}
\hline Null Hypothesis: & F-Statistic Prob. \\
\hline $\mathrm{REMI}_{\mathrm{t}}$ does not Granger Cause GDPGR ${ }_{\mathrm{t}}$ & 6.523860 .0164 \\
\hline GDPGR $_{t}$ does not Granger Cause REMI $t$ & 0.718460 .4038 \\
\hline $\mathrm{REMO}_{\mathrm{t}}$ does not Granger Cause GDPGR & t 14.86970 .0006 \\
\hline GDPGR $_{t}$ does not Granger Cause $\mathrm{REMO}_{t}$ & t 0.184990 .6704 \\
\hline $\mathrm{REMO}_{\mathrm{t}}$ does not Granger Cause $\mathrm{REMI}_{\mathrm{t}}$ & 0.002340 .9618 \\
\hline $\mathrm{REMI}_{\mathrm{t}}$ does not Granger Cause $\mathrm{REMO}_{\mathrm{t}}$ & $0.22035 \quad 0.6424$ \\
\hline
\end{tabular}

\section{Discussions}

The main aim of this paper was to investigate the relationship between remittance inflows and outflows on the economic growth rate of Japan. Consistent with the economic intuition, this study found that a $1 \%$ increase in $\mathrm{REMO}_{\mathrm{t}}$ will decrease GDPGR $\mathrm{t}_{\mathrm{t}}$ by $0.000793 \%$ in the long run. Equation three shows that remittance outflow will decrease the total consumption of the donor household (Donor country is the country that sends the remittances to other overseas countries.). The effect of remittance outflow on total consumption is transmitted via the income effect. According to the concept of the income effect, the change in real income is stimulated by the decrease in total disposable income that is caused by the increase in remittance outflows. This finding is consistent with the findings of the studies conducted by David and Maroni (2015). David and Maroni (2015) argued that remittance outflows from the donor country will reduce the domestic consumption and household disposable income. Equation seven shows that remittance outflows have a negative impact on the macroeconomic balance equation. The effect on the national income $\left(\mathrm{Y}_{\mathrm{t}}\right)$ is transmitted via the changes in national consumption $\left(\mathrm{C}_{\mathrm{t}}\right)$. The long run impact of remittance outflows on the Japanese economy is clearly evident by the stagnating economic growth of Japan in the recent decade. First, remittance outflow represents money channeled out of the Japanese economy; therefore, generating a loophole for investment, employment generation and economic growth activities. These money leakages act as injections for countries like China, Taiwan and South Korea that receive bulk of the remittance from Japan (Guha 2013). Second, migrant workers learn new skills from Japanese workers, innovative ideas and business acumen from business warehouses and these skills are easily transmitted from these workers to foreign competing nations, such as, China and South Korea.

Moreover, this study also found that in the short run, a $1 \%$ increase in remittance outflows and inflows will decrease GDP growth rate by $0.000599 \%$ and $0.000327 \%$ respectively. The short run economic impact of remittance outflows on economic growth supports the existing economic intuition that emphasises that remittance outflows reduces household income, thereby shifting the budget constraint line downwards and reduces national income and consumption. As expected, the short run effect of remittance outflows on economic growth rate is lesser than the long run effect. One of the main reasons underpinning this research finding is that in the short run less money is leaked out of the national economy as compared to the long run. As a result of this, long run negative effect of remittance outflow on the national economy will be much higher than the short run effect. Surprisingly, the short run effect of remittance inflows also has a negative effect on economic growth rate of Japan. There are three ways how the negative effect of remittance inflows may be transmitted to the Japanese economy in the short run. First, when Japanese skilled workers migrate to foreign countries, they transfer their knowledge, skills and talents to the innovation process of foreign countries; thereby, generating a skill gap in Japan. This skill gap and work ethics are not fully filled by migrant workers in Japan who may not be easily able to adopt Japanese ways of doing work. In the short run, the migrant workers may not be able to contribute as effectively to the innovation process because their productivity levels are much lower than the Japanese workers. This generates the innovation disturbance effect. In the context of Japan, this effect diminishes in the long run as the migrant workers are able to adjust to the Japanese ways of doing work. This research finding is in contrast to the findings from the studies conducted by Azam (2015). These studies found that remittance inflows have a positive impact on the economic growth rate of the developing countries. There are two reasons for these differences. First, developing countries usually receive more remittances than the developed countries, resulting in 
positive impact of remittance inflows on the economic growth rate of the developing countries. Second, in the context of the small island developing countries, remittances are one of the primary sources of positive economic growth. In the Pacific Island countries, such as Kiribati, remittances remitted through seafarers working on international commercial and shipping vessels have been providing the Kiribati economy with direct benefits to communities and families as this nation does not have an established social welfare system (Borovik 2006). As a result of this, the remittances provide a safety net for those families employed in the seafaring vessels.

Furthermore, the Granger Causality test shows that there is unidirectional causality running from remittance inflows and remittance outflows to GDP growth rate. Both remittance inflows and outflows have an effect on the Japanese economy. The Granger Causality test is not able to distinguish between the short run and long run effect; however, the findings from the Granger Causality test supports the short run and long run findings presented above.

\section{Policy Implications}

There are three important policy implications for this study. First, government policies should be directed towards reducing the number of foreign under skilled workers recruited by the Japanese companies to work in Japan. Friendly and cost effective remittance policies must be developed by the recipient countries. These policies should emphasise on less transaction costs and sound investment practices. The recruitment process of companies should be made stringent and regress to ensure that only skilled and qualified migrant workers enter the Japanese workforce. Second, government policies on retired workers should be reconsidered so that retired workers can return to the labour market and effectively contribute to the workforce. Policies on re-training of retired workers are needed so that less foreign migrant workers are needed and this will reduce remittance outflow. For example, in the US, banks are hiring retired women to be tellers in order to reduce the demand for migrant workers. Third, the Japanese government policies should be directed towards reducing the number of Japanese workers leaving the Japanese workforce. It has been proven that Japanese workers provide the best fit to the Japanese workforce so that higher productivity levels could be achieved. To nullify the innovation disturbance effect triggered in the short run, it is essential to provide attractive opportunities to the Japanese workers.

\section{Conclusion and Limitations}

The main aim of this study was to investigate the impact of remittance inflows and outflows on the economic growth rate of Japan. This study found that a $1 \%$ increase in $\mathrm{REMO}_{t}$ will decrease $\mathrm{GDPGR}_{\mathrm{t}}$ by $0.000793 \%$ in the long run. This study also found that in the short run, a $1 \%$ increase in remittance outflows and inflows will decrease GDP growth rate by $0.000599 \%$ and $0.000327 \%$ respectively. There are three important contributions of this study. First, this study found that in the short run, remittance inflows has a negative effect on the economic growth rate of Japan. This is contrary to the findings reported in the existing literature on the developing countries. The innovation disturbance effect explains why remittance inflow has negative effect on the economic growth rate of Japan. Second, this is the pioneering study that has investigated the effect of remittance inflows and outflows on the economic growth rate of Japan. Third, this study integrates the effect of remittance inflows and outflows on the budget constraint and macroeconomic balance equation.

One of the limitations of this study is that it is based on a single country. Similar studies should be conducted in other developed countries and a cross sectional comparison of the research findings should be done across these countries.

\section{References}

Acosta, P. A., Fajnzylber, P., \& Lopez, H. (2007). The impact of remittances on poverty and human capital: evidence from Latin American household surveys. World Bank Policy Research Working Paper, Washington DC: World Bank.

Adams, S., Kwame, E., \& Klobodu., M. (2016). Remittances, regime durability and economic growth in Sub-Saharan Africa. Economic Analysis and Policy, June, 50, 1-8.

Adarkwa, M. A. (2015). Impact of remittances on economic growth: Evidence from selected West African countries (Cameroon, Cape Verde, Nigeria and Senegal). African Human Mobility Review, 1(2), 177-200.

Adenutsi, D. E. (2011). Financial development, international migrant remittances and endogenous growth in Ghana. Studies in Economics and Finance, 28(1), 68-89.

Adhikary, B. K. (2011). FDI, trade openness, capital formation, and economic growth in Bangladesh: a linkage analysis. International Journal of Business and Management, 6(1), 16-28. 
Aggrawal, R., Demirguc-Kunt, A., and Peria, M. S. M. (2011). Do remittances promote financial development? Journal of Development Economics, November, 96(2), 255-264.

Azam, M. (2015). The role of migrant workers remittances in fostering economic growth: The four Asian developing countries' experiences. International Journal of Social Economics, 42(8), 690-705.

Bai, J. (1997). Estimation of a change point in multiple regression models. Review of Economics and Statistics, 79(4), 551-563.

Bai, J., \& Perron, P. (1998). Estimating and testing linear models with multiple structural changes. Econometrica, 66(1), 47-78.

Bettin, G., Presbitero, A. F., \& Spatafora, N. L. (2015). Remittances and vulnerability in developing countries. The World Bank Economic Review. Retrieved from https://wber.oxfordjournals.org/content/early/2015/09/29/wber.lhv053.full

Borovnik, M. (2006). Working overseas: Seafarers' remittances and their distribution in Kiribati. Asia Pacific Viewpoint, April, 47(1), 151-161.

Brown, R. P., \& Ahlburg, D. A. (1999). Remittances in the South Pacific. International Journal of Social Economics, 26(1/2/3), 325-344.

Calero, C., Bedi, A. S., \& Sparrow, R. (2009). Remittances, liquidity constraints and human capital investments in Ecuador. World Development, 37(6), 1143-1154.

Christensen, L.R., Jorgenson, D.W., \& Lau, L. J. (1973). Transcendental Logarithmic Frontiers. Review of Economics and Statistics, 55(1), 28-45.

Connell, J., \& Conway, D. (2000). Migration and remittances in island microstates: a comparative perspective on the South Pacific and the Caribbean. International Journal of Urban and Regional Research, 24(1), 52-78.

Cortes, P., 2015. The feminization of international migration and its effects on the children left behind: Evidence from the Philippines. World Development, Jan, 65, 62-78.

Cox-Edwards, A., \& Ureta, M. (2003). International Migration, Remittances, and Schooling: Evidence from El Salvador. Journal of Development Economics, 72(2), 429-461.

David, A. M. and Marouani, M. A., 2015. Migration and employment interactions in a crisis context. Economics of Transition, 23(3), 597-624.

Dey, S. (2015). Impact of remittances on poverty at origin: A study on rural households in India using covariate balancing propensity score matching. Migration and Development, 4(2), 185-199.

Elliott, G., Rothenberg, T., \& Stock, J. H. (1996). Efficient Tests for an Autoregressive Unit Root. Econometrica, 64(4), 813-836.

Gianneti, M., Federici, D., \& Raitono, M. (2009). Migrant remittances and inequality in Central-Eastern Europe, International Review of Applied Economics, May, 23(3), 289-307.

Goldfarb, R., Havrylyshyn, O., \& Mangum, S. (1984). Can remittances compensate for manpower outflows: The case of Philippine physicians. Journal of Development Economics, June-August, 15(1-3), 1-17.

Goto, J. (1998). The impact of migrant workers on the Japanese economy. Japan and the World Economy, January, 10(1), 63-83.

Growitsch, C., Jamasb, T., \& Pollitt, M. (2009). Quality of service, efficiency and scale in network industries: an analysis of European electricity distribution. Applied Economics, 41(20), 2555-2570.

Guha, P. (2013). Macroeconomic effects of international remittance: The case of developing economies. Economic modelling, 33, 292-305.

Gyimah-Brempong, K., \& Asiedu, E. (2015). Remittances and investment in education: Evidence from Ghana. Journal of International Trade \& Economic Development, 17 February, 24(2), 173-200.

Hamada, K., Otsuka, K., Ranis, G., \& Togo, K. (2011). Miraculous Growth and Stagnation in Post War Japan. UK: Routledge.

Harada, Y. (2016). Economic Activity, Prices and Monetary Policy in Japan. Speech at a Meeting with Business Leaders in Nagano, Bank of Japan, Japan.

International Monetary Fund. (2016). Subdued Demand \& Diminished Prospects: World Economic Outlook, 2016. Washington: IMF. 
Jackman, M., Craigwell, R., \& Moore, W. (2009). Economic volatility and remittances: evidence from SDS. Journal of Economic Studies, 36(2), 135-146.

Jawaid, S. T., \& Raza, S. A. (2012). Workers' remittances and economic growth in China and Korea: an empirical analysis. IDEAS Working Paper Series from RePEc. Retrieved from $\mathrm{http}: / /$ ideas.repec.org/p/pra/mprapa/39003.html

Kao, C., \& Chiang, M. H. (1999). On the estimation and inference of a Cointegrated regression in panel data. Available at SSRN 1807931.

Kerr, S. K., Kerr, W., Ozden, C., \& Parson, C. (2016). Global Talent Flows. The Journal of Economic Perspectives, Fall, 30(4), 83-106.

Knoema. (2016). Knoema Database, Washington DC: USA.

Kratou, H. (2016). Addressing the effect of workers' remittance on economic growth: evidence from MENA countries. International Journal of Social Economics, 43(1), 51-70.

Kumbhakar, S. C., \& Lovell, C. A. K. (2000). Stochastic Frontier Analysis, Cambridge: Cambridge University Press.

Mundaca, B. G. (2009). Remittances, Financial Market Development, and Economic Growth: the Case of Latin America and the Caribbean. Review of Development Economics, May, 13(2), 283-303.

Nica, E. (2014). The contribution of remittances to economic growth in developing countries. Economics, Management, and Financial Markets, 9(2), 115-120.

Peri, G. (2016). Immigrants, Productivity, and Labor Markets. The Journal of Economic Perspectives, Fall, 30(4), 3-39.

Perron, P. (2006). Dealing with structural breaks. Palgrave handbook of econometrics. USA: Palgrave Macmillan.

Phillips, P. C. B. (1987). Time Series Regression with a Unit Root. Econometrica, 55(2), 227-301.

Phillips, P. C. B., \& Perron, P. (1988). Testing for Unit Roots in Time Series Regression, Biometrika, 75(2), 335-346.

Phillips, P. C. B., \& Xiao, Z. (1998). A Primer on Unit Root Testing. Journal of Economic Surveys, 12(5), 423-470.

Pradhan, K. C. (2016). Does remittance drive economic growth in emerging economies: Evidence from FMOLS and Panel VECM. Theoretical and Applied Economics, 22(609), 57-74.

$\mathrm{Qu}, \mathrm{Z}$., \& Perron, P. (2007). Estimating and testing structural changes in multivariate regressions. Econometrica, 75(2), 459-502.

Rao, B. B., \& Hassan, G. M. (2012). Are the Direct and indirect Growth Effects of Remittances Significant? The World Economy, March, 351-372.

Tang, C. F., \& Abosedra, S. (2014). Small sample evidence on the tourism-led growth hypothesis in Lebanon. Current Issues in Tourism, 17(3), 234-246.

Taylor, E. J. (1999). The new economics of labour migration and the role of remittances in the migration process. International Migration, 37(1), 63-88.

Tekin, R. B. (2012). Economic growth, exports and foreign direct investment in Least Developed Countries: A panel Granger causality analysis. Economic Modelling, 29(3), 868-878.

Tezuka, K. (2016). Foreign Workers in Japan. Retrieved from https://publications.iadb.org/bitstream/handle/11319/759/Foreign\%20Workers\%20in\%20Japan.pdf?sequenc $\mathrm{e}=1$

University of Massachusetts Dartmouth. (2016). Detrending. Retrieved from http://terascan.smast.umassd.edu/nasdata/archive/achaudhu.old/docs/TIMESERIES/notes_7.pdf

World Bank. (2015). Remittances growth to slow sharply in 2015, as Europe and Russia stay weak; pick up expected next year. from http://www.worldbank.org/en/news/press-release/2015/04/13/remittances-growth-to-slow-sharply-in-2015-a s-europe-and-russia-stay-weak-pick-up-expected-next-year

World Bank. (2016). World Bank Database, Washington DC: World Bank. 
World Bank. (2017). World Bank National Accounts data. Retrieved from http://data.worldbank.org/indicator/NY.GDP.PCAP.CD

\section{Appendix 1}

Table A1. Estimated Long Run Beta Coefficients, t-Statistics and p Values LGDPGR $\mathrm{t}_{\mathrm{t}} \mathrm{LREMO}_{\mathrm{t}}$ and $\mathrm{LREMI}_{\mathrm{t}}$

\begin{tabular}{|l|r|r|r|r|}
\hline \multicolumn{1}{|c|}{ Variable } & Coefficient & Std. Error & t-Statistic & Prob. \\
\hline REMITTANCE_INFLOW & -0.000125 & 0.000604 & -0.207182 & 0.8373 \\
\hline REMITTANCE_OUTFLOW & -0.000793 & 0.000364 & -2.181501 & 0.0371 \\
\hline C & 3.722801 & 0.581496 & 6.402105 & 0.0000 \\
\hline R-squared & 0.371315 & Mean dependent var & 1.682742 \\
\hline Adjusted R-squared & 0.329403 & S.D. dependent var & 2.247814 \\
\hline S.E. of regression & 1.840735 & Akaike info criterion & 4.144715 \\
\hline Sum squared resid & 101.6491 & Schwarz criterion & 4.280761 \\
\hline Log likelihood & -65.38779 & Hannan-Quinn criter. & 4.190490 \\
\hline F-statistic & 8.859326 & Durbin-Watson stat & 2.355157 \\
\hline Prob(F-statistic) & 0.000947 & & & \\
\hline
\end{tabular}

Table A2. Estimated Short Run Beta Coefficients, t-Statistics and p Values LGDPGR, LREMO $_{\mathrm{t}}$ and LREMI

\begin{tabular}{|c|r|r|r|r|}
\hline Variable & Coefficient & Std. Error & t-Statistic & Prob. \\
\hline$\triangle L R E M I_{t}$ & -0.000327 & 0.000201 & -1.628295 & 0.1151 \\
\hline$\Delta L R E M O_{t}$ & -0.000599 & 0.000121 & -4.935341 & 0.0000 \\
\hline$E C T_{t}$ & 0.988696 & 0.060860 & 16.24553 & 0.0000 \\
\hline $\mathrm{C}$ & 3.593297 & 0.204907 & 17.53623 & 0.0000 \\
\hline R-squared & 0.935352 & Mean dependent var & 1.632058 \\
\hline Adjusted R-squared & 0.928169 & S.D. dependent var & 2.253936 \\
\hline S.E. of regression & 0.604084 & Akaike info criterion & 1.949706 \\
\hline Sum squared resid & 9.852757 & Schwarz criterion & 2.134736 \\
\hline Log likelihood & -26.22044 & Hannan-Quinn criter. & 2.010021 \\
\hline F-statistic & 130.2160 & Durbin-Watson stat & 2.030413 \\
\hline Prob(F-statistic) & 0.000000 & & & \\
\hline
\end{tabular}

\section{Copyrights}

Copyright for this article is retained by the author(s), with first publication rights granted to the journal.

This is an open-access article distributed under the terms and conditions of the Creative Commons Attribution license (http://creativecommons.org/licenses/by/4.0/). 